\title{
COMPARATIVE STUDY OF ANTIBACTERIAL AND ANTIFUGAL ACTIVITY OF CALLUS CULTURE AND ADULT PLANTS EXTRACTS FROM ALTERNANTHERA MARITIMA (AMARANTHACEAE)
}

\author{
Marcos J. Salvador ${ }^{1}$; Paulo S. Pereira² ${ }^{2}$ Suzelei C. França² ${ }^{2}$ Regina C. Candido ${ }^{3}$;zabel Y. Ito ${ }^{3}$; Diones A. Dias ${ }^{4,1 *}$ \\ ${ }^{1}$ Departamento de Química, Faculdade de Filosofia, Ciências e Letras de Ribeirão Preto, Universidade de São Paulo, Ribeirão \\ Preto, SP, Brasil; ${ }^{2}$ Unidade de Biotecnologia Vegetal, Universidade de Ribeirão Preto, Ribeirão Preto, SP, Brasil; \\ ${ }^{3}$ Departamento de Análises Clínicas, Toxicológicas e Bromatológicas, Universidade de Ribeirão Preto, Ribeirão Preto, SP, Brasil; \\ ${ }^{4}$ Departamento de Física e Química, Faculdade de Ciências Farmacêuticas de Ribeirão Preto, Universidade de São Paulo, \\ Ribeirão Preto, SP, Brasil.
}

Submitted: October 16, 2003; Returned to authors: January 29, 2004; Approved: April 13, 2004.

\begin{abstract}
The aim of this study was to evaluate the antibacterial and antifungal activity of callus culture (two different hormonal combination culture medium) and adult plants (two collect) extracts from Alternanthera maritima (Amaranthaceae) investigating the maintenance of antimicrobial activity in vivo and in vitro. The antibacterial and antifungal activity was determined by the agar-well diffusion method against thirty strains of microorganisms including Gram-positive and Gram-negative bacteria, yeasts and dermatophytes. All the organic crude extracts studied were bioactive. Extracts of aerial parts and roots of adult plants collected during the same period of years of 1995 and 1998 (Restinga de Maricá (RJ), collect 1 and 2) inhibited the growth of several microorganisms (bacteria, yeasts and dermatophytes) with inhibition halo between 6 and 20 $\mathrm{mm}$. Plant cell callus culture extracts obtained from two culture conditions were also bioactive. Thus, the positive results suggest that the A. maritima extracts should be further studied to determine the bioactive chemical compounds as well as to understand the possible mechanisms of action and evaluate their toxicity looking toward a pharmaceutical employment.
\end{abstract}

Key words: Alternanthera maritima, adult plants, callus culture, biotechnology, antimicrobial activity

\section{INTRODUCTION}

The use of medicinal herbs in the treatment of infection is an age-old practice and several natural products are used as phytotherapic for treatment of many diseases. Human infections constitute a serious problem and most frequent pathogens are microorganisms such as bacteria and fungi. On the other hand, the development of resistant strains of pathogenic bacteria to antibiotics currently in use is a problem of continuing concern to public health $(7,19)$. The fungal infections in the immunocompromised individuals have increased greatly in the recent years $(9,32)$ and these infections include important risk factors such as: neutropenia, leukopenia, chronic administration of corticosteroids and other antifungal agents, hepatotoxicity, cutaneous reactions and tissue lesions (24).

Nowadays, several antimicrobial drugs are available and particularly the antimycotic drugs present limited use by a number of factors, such as low potency, poor solubility, emergence of resistant strains and drug toxicity $(3,29)$. Therefore, the search for discovery of new antimicrobial agents is necessary and stimulates the research of new chemotherapeutic agents in the medicinal plants.

\footnotetext{
*Corresponding author. Mailing address: Departamento de Física e Química, Faculdade de Ciências Farmacêuticas de Ribeirão Preto, USP. Avenida do café, s/n. 14040903, Ribeirão Preto, SP, Brasil. Tel.: (+5516) 6024244. Fax: (+5516) 6332960. E-mail: mjsalvador@bol.com.br; diones@fcfrp.usp.br
} 
The Amaranthaceae family comprises many species with biological activities, which are used in nutrition and alternative medicine $(13,26,27)$. This family includes approximately 65 genera and 1000 species and many species of Gomphreneae tribe have been shown antimicrobial activity, such as Blutaparon portulacoides (26); Gomphrena martiana, G. boliviana $(22,23)$. The genus Alternanthera Forkssal includes 80 species and approximately 30 occur in Brazil (28). Many species of Aternanthera are used in the treatment of infections, as analgesic, anti-nociceptive, anti-viral and diurectic. Alternanthera maritima is commonly found on Brazil's eastern beaches and has been employed in studies of infections $(15,29)$. In the recent phytochemical study we have earlier reported the isolation and identification of steroids, saponins and flavonoids aglycones, $\mathrm{O}$ - and C-glycosides from aerial parts of A. maritima (25).

The development of plant cell cultures, nowadays, is an important strategy for bioprospection of natural products. Thus, the large-scale production in vitro of bioactive compounds or extracts used as phytotherapics, pharmaceutical products, food additives and cosmetics should be encouraged because of their scientific, economical or ecological importance $(1,2,4,5,11)$. However, the production in vitro of bioactive metabolites or extracts can be regarded as the result of the interaction of environmental conditions and the genotype of the cultured plant cells. Thus, factors like culture medium and their constituents (for example, carbohydrates, minerals, vitamins, phytohormones) light and temperature, control the metabolism, the growth, the induction of callus or obtainment of suspension cultures and the cell differentiation. Callus culture are plant cells undifferentiated and can be induced in function of hormonal combination employed and other environmental conditions as already described previously (12).

There is no report of biological studies in the literature about A. maritima, however in preliminary evaluation the crude extracts of adults plants has shown good antimicrobial activity. Therefore, the present work reports the results of the comparative study of antibacterial and antifungal activty of callus culture and adult plants extracts from A. maritima (Amaranthaceae), investigating the maintenance of antimicrobial activity in extracts from plants obtained in vivo and in vitro.

\section{MATERIALS AND METHODS}

\section{Plant material}

Alternanthera maritima (Mart.) St. Hil. (Amaranthaceae), aerial parts and roots, were collected at Restinga de Maricá, Rio de Janeiro, RJ, Brazil, on January 1995 (collect 1, collector number DAD0019) and December 1998 (collect 2, collector number DAD0035) and identified by Prof. Dr. Josafá Carlos de Siqueira ("Pontifícia Universidade Católica, Rio de Janeiro, RJ"). Voucher specimen was deposited at the Herbarium of the "Departamento de Biologia, Faculdade de Filosofia, Ciências e Letras de Ribeirão
Preto, Universidade de São Paulo, SP, Brasil” (register number SPFR 4758).

\section{Callus induction and maintenance}

Leaves from plantlets of A. maritima were washed in fresh tap water for $24 \mathrm{~h}$, treated with $1 \%$ Benomil (fungicide-antiseptic, Sigma) for $40 \mathrm{~min}$ and sterilized by stirring in $0.5 \%$ sodium hypochlorite solution for $20 \mathrm{~min}$, followed by three successive rinses in sterile distilled water. Leaf explants were inoculated in the basal medium of (MS) Murashige and Skoog (16) supplemented with 30.0 g.L.- sucrose (Aldrich) and $1 \%(\mathrm{w} / \mathrm{v})$ agar (Sigma) in two different hormonal combination: AmT43 [1.0 mg. $\mathrm{L}^{-1}$ 2,4-dichlorophenoxyacetic acid (2,4-D, Sigma) and $1.0 \mathrm{mg} . \mathrm{L}^{-1}$ kinetin (Kin, Sigma)] and AmT11 [2.5 mg.L-1 $\alpha-$ naphthaleneacetic acid (NAA, Sigma) and $1.0 \mathrm{mg} . \mathrm{L}^{-1}$ 6-benzylaminopurine (BAP, Sigma)]. Callus cultures were maintained on solid MS medium, subcultured every 30 days at $28 \pm 2^{\circ} \mathrm{C}$ with a daily photoperiod of 16 hours. Callus cultures were harvested at day 30 of cultivation and dried at $60^{\circ} \mathrm{C}$.

\section{Extracts preparations}

Aerial parts and roots dried and powdered of A. maritima adult plants collected during the same period of years 1995 and 1998 (collect 1 and 2) were extracted exhaustively by maceration using hexane and ethanol successively in the proportion powder mass plant/solvent 1:2(w/v). The spent biomass was filtered from the extracts and the solvents were removed under vacuum in a rotatory evaporator (below $40^{\circ} \mathrm{C}$ ), to obtain the hexanic and ethanolic crude extracts from aerial parts (AmPah, AmPae) and roots (AmRh, AmRe), respectively. The aqueous lyophilized extracts (aerial parts and roots) were prepared in hot (FAHL) and cold (FACL) water, as described by Zucchi et al. (33).

Dry tissue obtained from two different hormonal combination medium (AmT43 and AmT11) was powered and successively extracted, in the proportion powder mass of callus culture/ solvent 1:2 (w/v), with hexane, chloroform and ethanol at room temperature and overnight extraction. Hexane, chloroform and ethanol extracts were grouped of each callus culture medium and the solvent evaporated under vacuum in a rotatory evaporator (below $40^{\circ} \mathrm{C}$ ).

\section{Susceptibility testing \\ Strains of microorganisms used}

Susceptibility tests were performed using thirty strains of microorganisms including Gram-positive (fifteen strains) and Gram-negative bacteria (four strains), yeasts (seven strains) and dermatophytes (four strains) (Table 1). These microorganisms were collected from "Departamento de Análises Clínicas, Toxicológicas e Bromatológicas, Faculdade de Ciências Farmacêuticas de Ribeirão Preto, Universidade de São Paulo (FCFRP/USP), Ribeirão Preto-SP, Brasil”. 


\section{Determination of antimicrobial activity}

Sensitivity tests were performed by agar-well diffusion method (well technique in double layer) according to Cole (8), Espinel-Ingroff et al. (10), Grove and Randall (14), Okeke et al. (20) and Pujol et al. (24) with modifications. The test bacterial and fungi strains were inoculated into Mueller Hinton Medium (Difco)-MH agar plates (Escherichia, Pseudomonas, Micrococcus and Staphylococcus strains), Brain Heart Infusion Agar (Difco)-BHIa plates (Enterococcus and Streptococcus strains) and RPMI - 1640 Medium (Sigma) with MOPS (USB)

Table 1. Antibacterial and antifungal activity of organic extracts from callus culture (two culture medium, T11 and T43) and adult plants (two collects) of Alternanthera maritima.

\begin{tabular}{|c|c|c|c|c|c|c|c|c|c|c|c|c|c|c|}
\hline \multirow[t]{4}{*}{ Microorganisms } & \multicolumn{14}{|c|}{ Tested material } \\
\hline & \multicolumn{8}{|c|}{ Adult plants extracts } & \multicolumn{2}{|c|}{$\begin{array}{c}\text { Calus culture } \\
\text { extracts }\end{array}$} & \multicolumn{4}{|c|}{ Experimental controls } \\
\hline & $\begin{array}{c}\text { Am } \\
\text { Pae } 1\end{array}$ & $\begin{array}{c}\text { Am } \\
\text { Pah1 }\end{array}$ & $\begin{array}{l}\text { Am } \\
\operatorname{Re} 1\end{array}$ & $\begin{array}{l}\text { Am } \\
\text { Rh1 }\end{array}$ & $\begin{array}{c}\mathrm{Am} \\
\mathrm{Pae} 2\end{array}$ & $\begin{array}{c}\text { Am } \\
\text { Pah2 }\end{array}$ & $\begin{array}{l}\text { Am } \\
\text { Re2 }\end{array}$ & $\begin{array}{l}\text { Am } \\
\text { Rh2 }\end{array}$ & $\begin{array}{l}\mathrm{Am} \\
\mathrm{T} 11\end{array}$ & $\begin{array}{l}\mathrm{Am} \\
\mathrm{T} 43\end{array}$ & $\mathrm{Gen}^{\mathrm{c}}$ & $\mathrm{Bac}^{\mathrm{c}}$ & $\mathrm{Ket}^{\mathrm{c}}$ & $\begin{array}{c}\text { Prop/ } \\
\text { RPMI }^{\mathrm{d}}\end{array}$ \\
\hline & $\mathrm{H}$ & $\mathrm{H}$ & $\mathrm{H}$ & $\mathrm{H}$ & $\mathrm{H}$ & $\mathrm{H}$ & $\mathrm{H}$ & $\mathrm{H}$ & $\mathrm{H}$ & $\mathrm{H}$ & $\mathrm{H}$ & $\mathrm{H}$ & $\mathrm{H}$ & $\mathrm{H}$ \\
\hline Micrococcus luteus (ATCC 9341) & 9 & 8 & 7 & 7 & - & 8 & 8 & 8 & $\mathrm{t}$ & - & 28 & 25 & - & - \\
\hline Staphylococcus aureus (ATCC6538) & 9 & 8 & - & 6 & 7 & 10 & 7 & 9 & 6 & 6 & 26 & 23 & - & - \\
\hline S. aureus $($ ATCC 25923) & - & - & - & - & - & - & - & - & - & - & 28 & 29 & - & - \\
\hline S. aureus (ATCC 25213) & - & - & - & - & 7 & 8 & - & 8 & - & - & 28 & 29 & - & - \\
\hline S. aureus penicilinase $+(7+)^{\mathrm{b}}$ & 11 & 10 & 5 & 9 & 7 & 9 & $\mathrm{t}$ & 10 & 6 & 6 & 28 & 25 & - & - \\
\hline S. aureus penicilinase $-(8-)^{b}$ & - & - & - & - & - & 7 & - & 8 & - & - & 26 & 25 & - & - \\
\hline Staphylococcus epidermidis (6ep) ${ }^{\mathrm{b}}$ & 8 & - & - & - & - & - & - & - & - & 6 & 27 & 31 & - & - \\
\hline Streptococcus mutans (ATCC 25175) & 12 & 10 & - & - & - & 8 & - & - & 9 & 6 & 23 & 24 & - & - \\
\hline S. mutans $(\mathrm{Fab} 3)^{\mathrm{a}}$ & 10 & 8 & - & - & - & 9 & - & - & 8 & 6 & 24 & 22 & - & - \\
\hline S. mutans $(11.1)^{\mathrm{b}}$ & 8 & 8 & - & - & $\mathrm{t}$ & 8 & - & - & 7 & - & 20 & 22 & - & - \\
\hline S. mutans $(9.1)^{\mathrm{b}}$ & 10 & 7 & - & - & 9 & 8 & 8 & 9 & 6 & - & 21 & 22 & - & - \\
\hline S. mutans $(9.31)^{\mathrm{b}}$ & 8 & 7 & - & - & 9 & 9 & 8 & 10 & 7 & 6 & 20 & 22 & - & - \\
\hline S. mutans $(11.22 .1)^{\mathrm{b}}$ & 12 & 9 & - & - & 10 & 10 & 8 & 8 & 6 & 6 & 22 & 24 & - & - \\
\hline Streptococcus sobrinus $(180.3)^{\mathrm{b}}$ & 9 & 9 & 8 & 8 & 9 & 6 & 10 & 10 & 8 & 7 & 24 & 23 & - & - \\
\hline Enterococcus faecalis $(\text { ATCC } 10541)^{\mathrm{a}}$ & - & - & - & - & - & - & - & - & - & - & 22 & 28 & - & - \\
\hline Escherichia coli $(\text { ATCC } 10538)^{\mathrm{a}}$ & 8 & 8 & 5 & - & 8 & 8 & 8 & 8 & 6 & 8 & 30 & 32 & - & - \\
\hline E. coli $(\mathrm{ec} 26.1)^{\mathrm{b}}$ & - & - & - & - & - & - & - & - & - & - & 30 & 32 & - & - \\
\hline Pseudomonas aeruginosa (ATCC 27853) & 7 & 7 & - & - & 8 & 8 & - & - & 7 & $\mathrm{t}$ & 25 & 22 & - & - \\
\hline P. aeruginosa $(290 \mathrm{D})^{\mathrm{b}}$ & - & - & - & - & - & - & - & - & - & - & 24 & 22 & - & - \\
\hline Candida albicans (ATCC 1023) ${ }^{\mathrm{a}}$ & - & - & - & - & - & - & - & - & - & - & - & - & 40 & - \\
\hline C. albicans (ATCC 64548) & 7 & 7 & - & 8 & 7 & 7 & - & 8 & - & - & - & - & 40 & - \\
\hline C. albicans (cas) $)^{\mathrm{b}}$ & - & - & - & - & - & - & - & - & - & - & - & - & 20 & - \\
\hline Candida tropicalis $(\mathrm{ct})^{\mathrm{b}}$ & - & - & - & - & - & - & - & - & 7 & 7 & - & - & 40 & - \\
\hline Candida glabrata (ATCC 90030) & 8 & 7 & - & 7 & 9 & 9 & 6 & 9 & 10 & 10 & - & - & 22 & - \\
\hline Candida krusei (ATCC 6258) & 7 & - & - & - & $\mathrm{t}$ & - & - & - & - & - & - & - & 18 & - \\
\hline Candida parapsilosis (ATCC 22019) & - & - & - & - & - & - & - & - & - & - & - & - & 35 & - \\
\hline Trichophyton rubrum $(\operatorname{Tr} 5)^{\mathrm{b}}$ & $12(18) *$ & $12(12) *$ & -6 & $6(16)^{*}$ & $6(14)^{*}$ & $6(18)^{*}$ & - & $6(18)^{*}$ & $7(10)^{*}$ & $7(15)^{*}$ & - & - & 30 & - \\
\hline T. rubrum $(\operatorname{Tr} 19)^{\mathrm{b}}$ & $7(12)^{*}$ & $12(20)^{*}$ & - & - & $6(12)^{*}$ & $6(12) *$ & - & - & 10 & 7 & - & - & 30 & - \\
\hline Trichophyton mentagrophytes $(\mathrm{Tm} 9)^{\mathrm{b}}$ & 7 & 8 & - & - & - & 8 & - & - & 10 & 7 & - & - & 20 & - \\
\hline T. mentagrophytes $(\mathrm{Tm} 17)^{\mathrm{b}}$ & - & 7 & - & - & - & 9 & - & - & 10 & 7 & - & - & 35 & - \\
\hline
\end{tabular}

$\mathrm{H}$ : halo (diameter) of inhibition; -: without inhibition of the development; t: trace of inhibition; *: trailing effect after $6^{\circ}$ day of incubation; ${ }^{a}$ standard strain; ${ }^{b}$ strain of collection of microbiology and micology laboratories of FCFRP/USP; ${ }^{c}$ positive experimental control [Gen=gentamicine disks $(10 \mathrm{mg})$; Bac=bacitracine $(0.2 \mathrm{UI} / \mathrm{mL})$ for bacteria strains and Ket=ketoconazole $(100 \mathrm{mg} / \mathrm{mL})$ for fungi strains]; ${ }^{\mathrm{d}}$ negative experimental control [propyleneglycol/RPMI-1640 (5:95)]; AmPae: ethanolic extract of aerial parts, adult plants-collect 1 and 2; AmPah: hexanic extract of aerial parts, adult plants-collect 1 and 2; AmRe: ethanolic extract of roots, adult plants-collect 1 and 2; AmRh: hexanic extract of roots, adult plants-collect 1 and 2; AmT11 and AmT43: callus culture extracts obtained from two different hormonal combination medium. 
buffer solutions in agar plates (Candida and Trichophyton strains), containing an inoculum size of $10^{6} \mathrm{cfu} / \mathrm{ml}(0.5 \mathrm{McFarland}$ scale). The inoculum size of each test strain was standardized according to the National Committee for Clinical Laboratory Standards [NCCLS, 1993 (17); 1998 (18)].

Aliquots of $20.0 \mu \mathrm{l}$ of each test-drug solution were applied into $5.0 \mathrm{~mm}$ diameter wells. For these studies the solutions were prepared in propyleneglycol/RPMI-1640 (5:95) at $5.0 \mathrm{mg} / \mathrm{ml}$ for all the crude extracts.

After holding the plates at room temperature for 2 hours to allow diffusion of test-drug into the agar, they are incubated for 24 and 48 hours at $37^{\circ} \mathrm{C}$ for the bacteria and yeast strains, respectively, and for 6 days at $30^{\circ} \mathrm{C}$ for the dermatophytes. For Enterococcus and Streptococcus strains the incubation were performed in microaerofilic conditions. The inhibition zone, corresponding to the halo $(\mathrm{H})$ formed from well edge to the beginning of the region of microbial growth was measured in millimeters $(\mathrm{mm})$. In these tests, gentamicine disks $(10 \mu \mathrm{g})$, bacitracine $(0.2 \mathrm{UI} / \mathrm{ml})$ and ketoconazole $(100 \mathrm{mg} / \mathrm{ml})$ were used as experimental positive controls for strains analyzed, while propyleneglycol/RPMI-1640 (5:95) served as the negative control.

For dermatophytes the samples of inhibition zone were subcultured on Sabouraud glucose agar for 6 days at $30^{\circ} \mathrm{C}$ for confirmation of the inhibition of microbial growth.

The tests were performed in duplicates for each microorganism evaluated and the final results were presented as the arithmetic average.

\section{RESULTS}

The data pertaining to the antibacterial and antifungal potential of the callus culture and adults plants extracts of $A$. maritima are presented in Table 1 . The bioactivity was maintenance for the extracts obtained of the plant collected during the same period of years 1995 and 1998 (collect 1 and 2) and for the extracts from callus culture obtained from two different hormonal combination medium.

The gentamicine $(10 \mu \mathrm{g} /$ disk $)$ and bacitracine $(0.2 \mathrm{UI} / \mathrm{mL})$ here used as a positive experimental control against all bacteria strains assayed, produced halo of inhibition $(\mathrm{H})$ of $22-32 \mathrm{~mm}$, while ketoconazole $(100 \mu \mathrm{g} / \mathrm{mL})$ served as the positive experimental control for all fungi strains assayed with halo of inhibition of 12-35 mm (Table 1). The media containing propyleneglycol/ RPMI-1640 (5:95) was used as negative control for which no inhibitory effect could be observed.

\section{DISCUSSION}

The organic crude extracts from callus culture and adult plants of A. maritima were considerably active against microorganisms evaluated, while the aqueous lyophilized extracts from adult plants (aerial parts and roots) prepared in hot and cold water did not interfere appreciably (at $5.0 \mathrm{mg} / \mathrm{mL}$ ) with the growth of microorganisms tested.

It was found that the adult plants extracts from two different collect (1 and 2) were bioactive against Gram-positive and Gramnegative bacteria, yeasts and dermatophytes, with antimicrobial activity mainly associated with Gram-positive bacteria and filamentous fungi. The aerial parts of adult plants extracted with ethanol and hexane were shown to be active against nineteen strains of microorganisms with predominance for Streptococcus and Trichophyton (all strains tested), while extracts of roots were active only against eight strains. The inhibition halo produced for organic extracts from adult plants were in the range of 6 and $20 \mathrm{~mm}$.

The plant cell callus culture extracts (AmT11 and AmT43) in two different hormonal combination were also bioactive and with bioactivity, in general, against the same strains of adult plants extracts. Nevertheless, with value of inhibition halo small, in the range of 6 and $15 \mathrm{~mm}$. This fact can have been happening due to presence in smaller concentration of the antimicrobial compounds in the plant cell callus culture and this hypothesis needs to be evaluated. On the other hand, in two different culture medium (AmT11 and AmT43) between 60-80\% of the A. maritima leaf explants were calli formed and showed similar antibacterial and antifungal active despite the different hormonal composition of the culture medium. Therefore, occurred the maintenance of the antimicrobial activity for plants extracts obtained in vivo and in vitro. The results obtained for cell culture of A. maritima are in accordance to results reported by of Thien and Goslinska (31) with culture of Solidago virgaurea L., being possible the maintenance the biological activity of plants in vitro cultures.

As indicated in Table 1, the extacts assayed were ineffective against S. aureus (ATCC 25923), E. faecalis (ATCC 10541), E. coli (strain ec 26.1), P. aeruginosa (strain 290D), C. albicans (strains ATCC 1023 and cas) and C. parapsilosis (ATCC 22019).

The antimicrobial agents in all the extracts are not known yet. However, previous chemical analysis of the adult plants extracts of collect 1 (25), indicated the presence of flavonoids, steroids and saponins. Some of these compounds have been shows antimicrobial activity as reported by Chattopadhyay et al. (6) and Pena et al. (21).

Nevertheless, further studies are needed, including in vitro and in vivo investigations, toxicity evaluation as well as the purification of active antibacterial and antifungal constituents from A. maritima extracts looking toward a pharmaceutical employment.

\section{ACKNOWLEDGEMENTS}

We are grateful to Professor J. C. de Siqueira for identifying the plant material; to FAPESP for funds and fellowship given to the first author and to CNPq for financial support. 


\section{RESUMO}

\section{Estudo comparativo da atividade antibacteriana e antifúngica de extratos obtidos da cultura de calos e da planta adulta de Alternanthera maritima (Amaranthaceae)}

Neste estudo procedeu-se a avaliação da atividade antibacteriana e antifúngica dos extratos brutos de Alternanthera maritima (Amaranthaceae) planta in natura de duas coletas distintas e obtidos por cultura de células buscando-se averiguar a manutenção da atividade antimicrobiana dos extratos obtidos da planta in vivo e in vitro. A ação antibacteriana e antifúngica foi determinada pelo método de difusão em ágar (técnica do poço) utilizando-se trinta cepas de microrganismos indicadores (bactérias Gram-positivas e Gram-negativas, leveduras e dermatófitos). Todos os extratos obtidos com solventes orgânicos avaliados apresentaram-se bioativos com halos de inibição de 6 a $20 \mathrm{~mm}$. Os extratos da planta in natura das duas coletas (Restinga de Marica (RJ), verão de 1995 e 1998) inibiram o desenvolvimento de diferentes microrganismos (bactérias, leveduras e dermatófitos). Os extratos obtidos da cultura de calos desenvolvidos em duas condições de cultivo diferentes, também se mantiveram bioativos. Assim, os resultados obtidos encorajam a realização de novos estudos com esta espécie vegetal para se determinar quais as substâncias presentes nos extratos e que contribuem para a atividade biológica, como também para entender seu mecanismo de ação e avaliar sua toxicidade, visando uma possível aplicação farmacêutica.

Palavras-chave: Alternanthera maritima, plantas adultas, cultura de calos, biotecnologia, atividade antimicrobiana

\section{REFERENCES}

1. Alfermann, A.W.; Petersen, M. Natural product formation by plant cell biotechnology. Plant Cell, Tissue Organ Cult., 43:199-205, 1995.

2. Ames, T.T.; Worden, R.M. Continuous production of daidzein and genistein from soybean in a magnetofluidized bed bioreactor. Biotechnol. Prog., 13: 336-339, 1997.

3. Bisignano, G.; Tomaino, A.; Cascio, R.L.O.; Crisafi, G.; Uccella, N.; Saija, A. On the in-vitro antimicrobial activity of oleuropein and hydroxytyrosol. J. Pharm. Pharmacol., 51: 971-974, 1999.

4. Bouque, V.; Bourgaud, F.; Nguyen, C.; Guckert, A. Production of daidzein by callus cultures of Psoralea species and comparison with plants. Plant Cell, Tissue Organ Cult., 53: 35-41, 1998.

5. Bourgaud, F.; Gravot, A.; Milesi, S. Gontier, E. Production of plant secondary metabolites: a historical perspective. Plant Sci., 161: 839-851, 2001.

6. Chattopadhay, D.; Maiti, K.; Kundu, A.P.; Chakraborty, M.S.; Bhadra, R.; Mandal, S.C.; Mandal, A.B. Antimicrobial activity of Alstonia macrophylla: a folklore of bay islands. J. Ethnopharmacol., 77: 4955, 2001.

7. Cohen, M.L. Epidemiology of drug resistance: implications for a post-antimicrobial era. Science, 257: 1050-1055, 1992
8. Cole, M.D. Key antifungal, antibacterial and anti-insect assays- a critical review. Biochem. Syst. Ecol., 22: 837-856, 1994.

9. Dolande, M.; Reviáskina, V.; Panizo, M.; Maldonado, B. Diagnóstico immunológico de las micoses sistémicas en pacientes con SIDA (19972001). Rev. Ven. Microbiol., 22: 000-000, 2002.

10. Espinel-Ingroff, A.; Dawson, K.; Pfaller, M.; Anaissie, E.; Breslin, B.; Dixon, D.; Fothergill, A.; Paetznick, V.; Peter, J.; Rinaldi, M.; Walsh, T. Comparative and collaborative evaluation of standardization of antifungal susceptibility testing for filamentous fungi. Antimicrob. Agents Chemother, 39: 314-319, 1995.

11. Fu, T.J.; Singh, G.; Curtis, W.R. Plant Cell Culture for the Production of food ingredients. Kluwer Acad. Plenum, New York, 1999.

12. Gamborg, O.L.; Phillips, G.C. Plant cell, tissue and organ culturefundamental methods. Springer Verlag, New York, 1995.

13. Gorinstein, S.; Nue, J.; Arruda, P. Alcohol-soluble and total proteins from Amaranth seeds and their comparison with other cereals. $J$. Agric. Food Chem., 39: 848-850, 1991.

14. Grove, D.C.; Randall, W.A. Assay methods of antibiotics: a laboratory manual (Antibiotics monographs, 02). Medical Encyclopedia Inc. New York, 1955

15. Moraes, V.L.G.; Santos, L.F.M.; Castro, S.B.; Loureiro, L.H.; Lima, O.A.; Souza, M.L.M.; Yien, L.M.K.; Rossi-Bergmann, B.; Costa, S.S Inhibition of lymphocyte activation by extracts and fractions of Kalanchoe, Alternanthera, Paullinia and Mikania species. Phytomedicine, 1: 199-204, 1994.

16. Murashige, T.; Skoog, F. A revised medium for rapid growth and bioassays with tobacco tissue culture. Plant Physiol., 15: 473-497, 1962.

17. National Committee for Clinical Laboratory Standards. Methods for dilution in antimicrobial susceptibility tests. Approved standard M2-A5. National Committee for Clinical Laboratory Standard, Villanova, PA, 1993.

18. National Committee for Clinical Laboratory Standards. Reference method for broth dilution antifungal susceptibility testing of conidium-forming filamentous fungi. Proposed standard M38-P. National Committee for Clinical Laboratory Standard, Wayne, 1998, p.28.

19. Neu, H.C. The crisis in antibiotic resistance. Science, 257: 10501055,1992

20. Okeke, M.J.; Iroegbu, C.U.; Eze, E.N.; Okoli, A.S.; Esimone, C.O. Evaluation of extracts of the root of Landolphia owerrience for antibacterial activity. J. Ethnopharmacol., 78: 119-127, 2001.

21. Penna, C.; Marino, S.; Vivot, E.; Cruañes, M.C.; Muñoz, J.D.; Cruañes, J.; Ferraro, G.; Gutkind, G.; Martino, V. Antimicrobial activity of Argentine plants used in the treatment of infectious diseases. Isolation of active compounds from Sebastiania brasiliensis. J. Ethnopharmacol., 77: 37-40, 2001

22. Pomilio, A.B.; Buschi, C.A.; Tomes, C.N.; Viale, A.A. Antimicrobial constituents of Gomphrena martiana and Gomphrena boliviana. J. Ethnopharmacol., 36: 155-161, 1992.

23. Pomilio, A.B.; Sola, G.A.; Mayer, A.M.; Rumi, L.S. Antitumor and cytotoxic screen of 5,6,7-trisubstituted flavones from Gomphrena martiana. J. Ethnopharmacol., 44: 25-33, 1994.

24. Pujol, I.; Guarro, J.; Llop, C.; Soler, L.; Fernández-Ballart, J Comparison study of broth macrodilution and microdilution antifungal susceptibility tests for the filamentous fungi. Antimicrob. Agents Ch., 40: 2106-2110, 1996.

25. Salvador, M.J.; Dias, D.A. Flavone C-glycosides from Alternanthera maritima (Mart.) St. Hil. (Amaranthaceae). Biochem. Syst. Ecol., 32: 107-110, 2004

26. Salvador, M.J.; Ferreira, E.O.; Pral, E.M.F.; Alfieri, S.C.; Albuquerque, S.; Ito, I.Y.; Dias, D.A. Bioactivity of crude extract and some constituents of Blutaparon portulacoides (Amaranthaceae). Phytomedicine, 9: 566-571, 2002. 
27. Siqueira, J.C. Importância alimentícia e medicinal das Amaranthaceaes do Brasil. Acta Biologica Leopoldensia, 9: 5-22, 1987.

28. Siqueira, J.C. Phytogeography of brasilian Amaranthaceae. Pesquisa Botânica, 0: 5-21, 1994/1995.

29. Siqueira, J.C.; Guimarães, E.F. Amaranthaceae do Rio de Janeiro gênero Alternanthera Forsskal. Rodriguésia, 36: 21-40, 1984.

30. Soares, M.M.S.R.; Cury, A.E. In vitro activity of antifungal and antiseptic agents against dermatophyte isolates from patients with tinea pedis. Braz. J. Microbiol., 32: 130-134, 2001.
31. Thiem, B.; Goslinska, O. Antimicrobial activity of Solidago virgaurea L. from in vitro cultures. Fitoterapia, 73: 514-516, 2002.

32. Wheat, L.J. Fungal infections in the immunocompromised host. In: Rubin, R.H.; Young, L.S. (eds.). Clinical approach to infection in the compromised host. Plenum Publishing Corporation, New York, 1994, v.3, p.211-237.

33. Zucchi, O.L.A.D.; Dias, D.A.; Nascimento Filho, V.F.; Salvador, M.J. Characterization of two medicinal plants by X-ray spectrometry. J. Trace Microprobe Techniques, 18: 441-450, 2000. 